\title{
Restriction of FODMAP in the management of bloating in irritable bowel syndrome
}

Wei Mon Wong ${ }^{1,2,3}$, MBBS, MMed

\begin{abstract}
Irritable bowel syndrome (IBS) is a common functional bowel disorder. Up to $96 \%$ of IBS patients experience bloating, resulting in poor response to conventional therapies and high consultation rates. Many IBS patients report that food triggers symptoms, particularly diets with poorly absorbed, short-chain carbohydrates, and restrict intake of certain foods to control their symptoms. IBS patients are especially susceptible to an attack due to visceral hypersensitivity. An emerging therapeutic strategy excludes fermentable oligosaccharides, disaccharides, monosaccharides and polyols (FODMAP) from the diet. There is evidence supporting the efficacy of a low FODMAP diet in improving symptoms of bloating in IBS patients. Individualised, structured dietary guidance may benefit those with persistent troublesome symptoms despite traditional therapies. In view of the multifactorial aetiology of the condition, it is probably best to use a multipronged approach, involving combination therapies, to address bloating in IBS patients.
\end{abstract}

Keywords: bloating, FODMAPs, irritable bowel syndrome, low FODMAP diet

\section{INTRODUCTION}

Irritable bowel syndrome (IBS) is a common functional gastrointestinal tract disorder that is characterised by chronic and relapsing bloating, abdominal distension, abdominal discomfort or pain, flatulence, and altered bowel habits with no abnormal pathology. It can be diagnosed using the Rome III criteria. Prevalence rates of IBS vary from $2.9 \%$ to $30 \%{ }^{(1-3)}$ and its pathogenesis remains largely elusive. A myriad of hypotheses ${ }^{(4)}$ on the pathophysiological mechanism of IBS has been proposed, including altered intestinal mobility, visceral hypersensitivity, altered intestinal permeability, food intolerance, abdominal brain-gut interaction, ${ }^{(5)}$ imbalance of intestinal microbiota, and post-infectious and/or microscopic inflammatory changes.

Bloating is the most bothersome symptom that IBS patients experience. The symptoms of bloating are abdominal fullness and tightness, which is signified by abdominal distention. A majority of patients experience moderate or severe symptoms. Up to $96 \%$ of IBS patients ${ }^{(6)}$ experience bloating, compared to $20 \%-30 \%$ of the general population. ${ }^{(7,8)}$ Approximately $50 \%$ of patients with bloating also experience an increase in abdominal girth of up to $12 \mathrm{~cm}$. Bloating has a significant impact on quality of life $(\mathrm{QOL})^{(9)}$ and brings about great psychological distress.

Published guidelines ${ }^{(10,11)}$ recommend the use of antidiarrhoeals, laxatives, fibre supplements and high-fibre diets to improve transit disturbances; and antispasmodics or low-dose antidepressants for abdominal pain. However, these therapies have been unsatisfactory, and largely confer only symptomatic and transient relief. Up to $50 \%$ of IBS patients experience postprandial exacerbation of symptoms. ${ }^{(12,13)}$ Approximately $60 \%-80 \%$ of IBS patients believe that their symptoms are dietrelated, of which $75 \%$ of symptoms are related to incompletely absorbed carbohydrates. ${ }^{(14)}$ Many patients restrict their intake of certain foods to control their symptoms and are interested in the role of diet in IBS. ${ }^{(15-17)}$

Affluent countries see high consultation rates for IBS, with up to half of patients presenting to and being managed in primary care clinics. This corresponds to an increase in fermentable oligosaccharides, disaccharides, monosaccharides and polyols (FODMAP) intake (especially fructose) over the past three decades ${ }^{(18)}$ due to the increased availability of concentrated fruit juices and extensive use of high-fructose corn syrup in a wide variety of processed foods and beverages. Earlier studies ${ }^{(19,20)}$ on individual sugars and carbohydrates alluded to sugar malabsorption as a contributor to IBS symptoms; a significant reduction in IBS symptoms has been noted in individuals on a low FODMAP diet (LFD). Dietary, poorly absorbed, short-chain carbohydrates, collectively termed FODMAP, are found in a wide variety of foods, including those containing lactose, fructose in excess of glucose, fructan, galacto-oligosaccharides and polyols (i.e. sorbitol, mannitol, xylitol and maltitol). Ingestion of FODMAP increases delivery of readily fermented substrates and water to the distal small intestine and proximal colon, causing luminal distension and functional gut symptoms. The FODMAP concept hypothesis is that a global restriction should be more efficacious than a limited one in controlling IBS symptoms.

While bloating is a supportive symptom for a diagnosis of IBS, the Rome III diagnostic criteria for functional gastrointestinal disorders do not include bloating as a primary criterion for IBS because of its non-discriminatory nature. Up to $50 \%$ of patients who present with bloating do not fulfil the Rome III diagnostic criteria for IBS. ${ }^{(21)}$ As a result, despite the clinical relevance of this symptom, few studies have included bloating as a primary endpoint and, to the best of our knowledge, no studies have specifically examined the efficacy of an LFD in the management of

${ }^{1}$ Division of Primary Care, Raffles Medical Group, ${ }^{2}$ Division of Family Medicine, Department of Medicine, University Medicine Cluster, National University Hospital System, ${ }^{3}$ Duke-NUS Graduate Medical School, National University of Singapore, Singapore

Correspondence: DrWong Wei Mon, Consultant Family Physician, Division of Primary Care, Raffles Medical Group, 118 Holland Ave, \#05-02, Raffles Holland V, Singapore 278997. wong_weimon@rafflesmedical.com 
bloating. This review article systematically explores the available evidence to provide recommendations for managing bloating symptoms in IBS patients on an LFD.

\section{METHODOLOGY}

\section{Literature search}

A primary search of two electronic databases, PubMed and the Cochrane Central Register of Controlled Trials, was conducted using the search terms 'irritable bowel syndrome', 'FODMAP', 'FODMAPs', 'fermentable oligosaccharides disaccharides monosaccharides and polyols' or 'short chain fermentable carbohydrates' as keywords, and 'exploded' medical subject headings, when possible. The search was conducted from September 2014 to June 2015. Limits were applied for nonhuman studies and articles concerning children. A list of 237 articles was generated. A supplementary search of the archive of referenced articles yielded another three articles. ${ }^{(22,23,24)}$ This reference list of citations was screened based on appropriateness of the study title; 197 articles, including ten non-English articles and two duplicates, were excluded. The full text of the remaining 40 studies was extracted and reviewed for inclusion.

\section{Inclusion criteria}

English-language articles on FODMAP, symptoms and bloating in IBS patients were included. As dietary FODMAP composition is likely to vary with the type of cuisine, evidence from meta-analysis, systematic reviews, trials and case studies was evaluated to obtain a better understanding of an LFD in different cuisines. Expert opinions from the consensus guideline and position statement on this matter were also consulted. The primary outcome evaluated was improvement in bloating, while secondary outcomes were improvement in global or composite endpoint symptoms and QOL. Articles were excluded if the LFD was administered through the enteral route. Trials evaluating the effect of LFDs on healthy participants, inflammatory bowel disease, ileostomates and microbiota were not included. Randomised controlled trials (RCTs) were evaluated for risk of bias using the Jadad score (Table I). ${ }^{(25)}$ Recommendations were made according to the Strength Of Recommendations Taxonomy (Table II). ${ }^{(26)}$

\section{RESULTS}

\section{Papers selected}

Owing to the nature of the subject matter, there were limited highquality trials. A substantial proportion of the available literature were narrative reviews. 20 articles were used for this review, comprising one meta-analysis, one systematic review, nine RCTs, two non-randomised comparative studies, three prospective trials, one case study and three guidelines. Table I summarises the findings of the key articles.

Bloating has been included as part of a composite endpoint or as a secondary endpoint in studies targeted at IBS symptoms. Data from these studies were reviewed. Seven out of the 17 studies evaluated bloating as a secondary outcome, ${ }^{(6,22,27-31)}$ while the majority evaluated bloating as a composite endpoint. The IBS symptom severity score (SSS) was used in five ${ }^{(23,24,32-34)}$ of the ten studies that evaluated bloating as part of a composite endpoint, while the other ten studies used a varying visual analogue scale (VAS) or Likert scale.

\section{LFD improves bloating symptoms in IBS}

A significant reduction in bloating, either as a composite or secondary endpoint, was observed in most cohort studies and RCTs that used an LFD. Favourable response rates of $70 \%$ or more were reported..$^{(22,27,29,30,35)}$ Harvie, ${ }^{(24)}$ interestingly, reported no improvement in the severity of bloating despite a significant reduction in IBS SSS.

A systematic review ${ }^{(36)}$ reported overall improvement in IBS symptoms with a FODMAP-restricted diet. Recently, a meta-analysis $^{(37)}$ of pooled RCTs reported significant reduction in IBS SSS [odds ratio (OR) $0.44,95 \%$ confidence interval $(\mathrm{Cl})$ $0.25-0.76$; degree of heterogeneity $\left.\left(\mathrm{I}^{2}\right)=35.52, \mathrm{p}=0.00\right]$ and symptom severity for bloating (OR 1.75, 95\% Cl 1.07-2.87; $\left.\mathrm{I}^{2}=0.00, \mathrm{p}=0.45\right)$. Pedersen et al $\mathrm{I}^{(33)}$ noted a significantly greater improvement in SSS for the IBS-diarrhoea (IBS-D) subtype $(320 \pm 110$ to $153 \pm 136, p<0.01)$, although IBSassociated bloating is known to be more pronounced in cases with constipation. Patients with fructose malabsorption were also significantly more likely to report symptom improvement (OR 8.71, 95\% Cl 2.76-27.5). ${ }^{(31)}$

\section{LFD improves satisfaction with symptom control and QOL}

Satisfaction with symptom control increased ${ }^{(22)}$ with better control of bloating symptoms. In one study, $72 \%$ of LFD patients were satisfied with their symptom control. ${ }^{(31)}$ Improvement in QOL was also observed with an LFD. ${ }^{(24,33,38)}$ Meta-analysis data ${ }^{(37)}$ reported a significant improvement in the IBS-QOL score (OR 1.84, 95\% Cl 1.12-3.03; $\mathrm{I}^{2}=0.00, \mathrm{p}=0.39$ ).

\section{Graded dose response}

The response to FODMAP restriction corresponded to its dose. The composite endpoint for bloating was significantly higher in IBS patients on a high FODMAP diet (median 6, range 2-9) than an LFD (median 2, range 0-7; $p=0.002$ ). ${ }^{(29)}$ Similarly, improvement in bloating symptoms was significantly higher in IBS patients switching from a high FODMAP diet (median 3, range 0-3) than an LFD (median 1, range 0-3; $p=0.002$ ). ${ }^{(29)}$ Shepherd et al ${ }^{(28)}$ reported that the intensity of overall symptoms increased significantly as the dose of fructose, fructan and fructose-fructan mix was increased. However, it is unclear what the optimal dose and composition of an LFD should be. Halmos et al (27) limited FODMAP intake to no more than $0.5 \mathrm{~g}$ per meal. Ong et $\mathrm{al}^{(29)}$ set the limit for an LFD at $9 \mathrm{~g} /$ day. Most other studies in the literature made no mention of the exact content of the LFD.

\section{Differential effect of FODMAP types}

The fructose-fructan mix caused greater symptom severity; but there was no difference in symptoms between fructan and fructose alone. Improvement of bloating and symptom relapse (bloating, 
gas and pain) was seen more in IBS patients on the fructose-fructan $\operatorname{mix}(79 \%)$ compared to patients on fructan $(77 \%)$, fructose $(70 \%)$ and glucose $(14 \%)(p<0.001) .{ }^{(28)}$

\section{Time to response and duration of LFD therapy}

Time-to-response data varied from 2-8 weeks and symptom reduction was more evident nearer or after six weeks. ${ }^{(33,39)}$ Prompt response to therapy in as early as two days' time is possible. ${ }^{(28)}$ In individuals for whom osmotic and motility changes are the only mechanisms causing symptoms, rapid response to LFDs (within 24-48 hours) may be expected.

\section{LIMITATIONS}

The prospective observational (cohort) studies pointed to a temporal relationship between bloating and FODMAP exposure, while the RCTs provided evidence for causal relationships and supported changes in clinical practice. The RCTs reviewed had a low-to-moderate risk of bias, as assessed by the Jadad score. However, an inherent flaw of the Jadad score is that it does not take into account allocation concealment, which could overestimate the treatment effect by $20 \%-30 \%$. ${ }^{(40)}$ A reanalysis of the papers revealed that allocation concealment was reported in three ${ }^{(27,29,33)}$ of the nine RCTs. In addition, nonRCT evidence was not critically appraised. Notwithstanding the methodological flaws within the component studies, consistent results were seen across the different studies. In the rechallenge ${ }^{(28)}$ and crossover ${ }^{(27,29,34)}$ trials, patients served as their own controls to evaluate the efficacy of LFDs over a period of time.

Current evidence on the positive effects of FODMAP restriction on IBS-related bloating symptoms and QOL comes from studies with heterogeneous diagnostic criteria, SSS, study design, composition of LFD and duration of follow-up. Different diagnostic criteria abound, with the Rome III criteria being favoured. These studies have little mention of the various IBS subtypes. Different SSSs were employed, with the IBS SSS being the preferred scale in recent years. In addition, the articles included in this paper were limited to those published in English. It would be interesting to examine if the non-English articles suggest the same trends.

\section{DISCUSSION}

It appears that IBS patients who may benefit from LFDs include those with (a) bloating who fail to respond to conventional interventions as per treatment guidelines; (b) self-reported bloating symptoms attributed to possible food intolerance, especially fructose intolerance; and (c) IBS-D subtype. As up to half of patients who present with bloating do not fulfil the Rome III diagnostic criteria for IBS, ${ }^{(21)}$ physicians should keep an open mind to exclude other pathologies, such as small intestinal bacterial overgrowth, which could present with bloating.

Evidence points to a favourable response in IBS patients with bloating treated with a FODMAP-restricted diet, and a differential response in terms of FODMAP dose and type. The ideal composition of an LFD is, however, hazy at present.
Current researchers have experimented with American, British, Nordic, Australian and New Zealand cuisines. Limited literature regarding non-Western cuisines, such as Asian, is a prevailing issue. Data from non-English (Korean) manuscripts would add invaluable knowledge to this arena. Gwee et al ${ }^{(1)}$ highlighted the following differences in Asian IBS patients: (a) a low female predominance in the majority of Asians; (b) a high prevalence of lactose malabsorption amongst Asians; (c) faster intestinal transit times in both healthy and IBS patients in some Asian populations compared to the West; and (d) chilli consumption, in particular, as an aggravating dietary trigger. Evidence for the association between chilli and symptom aggravation was, however, weak. Considering these differences, Asian patients are likely to respond differently. That said, with globalisation, the Western diet has infiltrated many Asian countries. Diseases, such as inflammatory bowel diseases, that were once thought to be limited to the Western world, are quickly becoming a norm in Asia. ${ }^{(41,42)}$ Research into the Asian patient and diets could help to shed light in this area. In addition, research is also needed to determine the FODMAP content of other cuisines and discover more foods with restricted FODMAP content.

In addition to comparing the LFD with traditional cuisines, LFDs were compared with traditional IBS advice, ${ }^{(43,44)}$ which includes (a) having small, frequent meals; (b) to peel and divide foods into pieces; (c) chew thoroughly; (d) boil food; and (e) reduce fatty and spicy foods, legumes, onions, coffee and alcohol. In addition, carbonated beverages and sweeteners containing polyols should be avoided, and fibre intake should be evenly distributed over the day. Böhn et al ${ }^{(32)}$ compared the effects of adopting traditional IBS dietary advice with an LFD, and reported no difference in efficiency regarding the reduction of gastrointestinal symptoms of IBS. Reduction in the IBS SSS was similar between the two groups $(p=0.64)$ and among the individual items of the IBS SSS $(p=0.69)$. A trend of a larger reduction in abdominal distension in the traditional diet group was also observed. However, a non-randomised trial reported conflicting results; Staudacher et $\mathrm{al}^{(30)}$ reported improvement in bloating [(32/39) 82\% vs. (17/35) 49\%, ( $p=0.002)]$ when written information on LFDs was compared with standard dietary advice. While further research is needed to draw conclusions, the FODMAP-restricted diet still has a role in alleviating bloating symptoms in IBS patients.

The National Institute for Health and Care Excellence guidelines $^{(44)}$ strongly advocate self-help, structured patient education and other non-pharmacologic strategies such as lifestyle and diet modification. Previous studies have established the importance of offering education, information and general support in the management of IBS. Given individually or to a group, ${ }^{(38,45)}$ advice and guidance on FODMAP restriction is a cost-effective therapy in the management of IBS-related bloating. Nevertheless, the ideal mode and medium for patient education remain debatable. While most trials involved a FODMAPcertified dietitian, a nurse-led dietary guidance consisting three 45 -minute sessions ${ }^{(38)}$ resulted in a favourable symptom response $(41.47 \pm 1.62$ to $35.71 \pm 1.12 ; p=0.001)$; hence, written 
information and a food list on LFD choices may be as effective as a dietitian consult. Improvement in bloating was reported by Staudacher et al, ${ }^{(30)}$ who evaluated written information on LFDs versus 'standard' diets ( $82 \%$ vs. $49 \% ; p=0.002)$. In de Roest et $\mathrm{al}^{\prime} \mathrm{s}^{(31)}$ study, $18.2 \%$ of the subjects felt that a food list was as effective as a dietitian consult. Web-based self-management programmes have also proven to be feasible approaches to chronic diseases. A significant reduction in symptom severity was reported by Pedersen et $\mathrm{al}^{(33)}$ when a Web-based application was utilised to provide education, disease recognition and general support prior to dietitian-guided LFDs.

Hitherto, no validated biomarkers have been established for objective measurement of predominant IBS symptoms such as bloating. Consequently, patient-reported outcomes of symptom severity were relied on to evaluate symptom improvement. The validated IBS SSS ${ }^{(35)}$ appeared to provide a reliable measure of the overall severity of IBS. It contains five questions that measure bloating, among other symptoms, on a 100-point VAS. Presented in a traffic light system (Appendix) similar to the Written Asthma Action Plan, the IBS SSS serves as a simple tool to assess symptom severity and monitor response to therapy. In the traffic light system, red indicates severe symptoms, yellow moderate symptoms and green mild symptoms or remission.

Across trials, the adherence rate had a range of $20 \%-40 \%$, illustrating patients' difficulty with this restrictive diet. This is not surprising, given the highly intensive demands of an LFD. Factors such as ease of finding suitable food products, palatability of the diet, cost, patient understanding and personal motivation contribute to the plausibility and success of such a management strategy. ${ }^{(22,28)}$

The relatively short duration (range 154-251 days) of recently published studies did not allow sufficient time to gauge the sustainability of the effect of dietary changes. Concerns have been voiced about the nutritional value and adequacy of the LFD, although minimal adverse reactions have been reported. It is reassuring to note that no statistical difference in the intake of calories, carbohydrates, proteins and fat has been reported between the control and IBS patients. ${ }^{(35,46)}$ However, FODMAPs have prebiotic effects due to the production of short-chain fatty acids after fermentation. Long-term effects of LFDs on the gut microbiota and nutritional state of patients have yet to be evaluated.

Slightly more than one-third of the patients in Pedersen et al's study received conventional IBS medication, such as laxatives, antispasmodic and antidiarrheal agents, and antidepressants. Patients on IBS medication and LFDs responded significantly better than patients on LFDs alone. The improved response to combined therapy could be due to the complexity of IBS symptoms and the natural disease course of IBS, which requires medication that is effective against specific symptoms. ${ }^{(33)}$ Constipation-predominant IBS requires initial treatment aimed at ensuring that constipation is adequately and aggressively managed. ${ }^{(47)}$

The findings in this paper may represent the biased view from a single reviewer. Retrospectively, we could have involved a second independent reviewer to perform the literature search and a third-party arbitrator to address any disagreement, to ensure the robustness of this paper. Nonetheless, there is a consistent trend suggesting that LFDs improve bloating symptoms in IBS patients.

\section{CONCLUSION}

The LFD approach to the management of IBS patients is an emerging therapy. Current evidence supports the efficacy of LFDs in improving IBS-related bloating symptoms, which is a patient-important outcome. IBS is a chronic condition and, as in most chronic illnesses, awareness and education can empower the patient, foster self-efficacy in symptom control and liberate the IBS patient. Individualised, structured dietary guidance may benefit those with persistent, troublesome symptoms despite traditional therapies. However, given the multi-factorial aetiology of bloating in IBS, a multipronged approach involving a plurality of therapies is probably prudent.

Table I. Summary of relevant papers.

\begin{tabular}{|c|c|c|c|c|c|}
\hline Study, year; country & Design & $\begin{array}{c}\text { IBS } \\
\text { classification }\end{array}$ & Characteristics & Results & $\begin{array}{l}\text { Quality of } \\
\text { RCT (Jadad } \\
\text { score) }\end{array}$ \\
\hline $\begin{array}{l}\text { Marsh et al, } 2015^{(37)} \text {; } \\
\text { Australia }\end{array}$ & Meta-analysis & - & $\begin{array}{l}6 \text { RCTs, } \\
16 \text { non-RCTs } \\
\text { Random effects model }\end{array}$ & 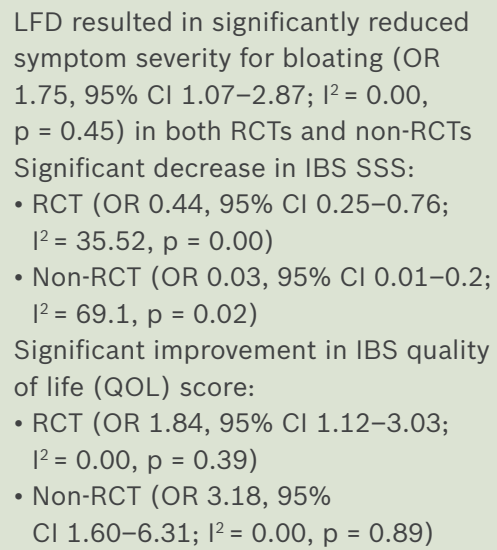 & - \\
\hline
\end{tabular}

(Contd...) 


\begin{tabular}{|c|c|c|c|c|c|}
\hline Study, year; country & Design & $\begin{array}{c}\text { IBS } \\
\text { classification }\end{array}$ & Characteristics & Results & $\begin{array}{l}\text { Quality of } \\
\text { RCT (Jadad } \\
\text { score) }\end{array}$ \\
\hline $\begin{array}{l}\text { Rao et al, } 2015^{(36)} \\
\text { United States }\end{array}$ & Systematic review & - & 6 RCTs & $\begin{array}{l}\text { Significant heterogeneity in } \\
\text { methodology (subject selection, } \\
\text { interventions and outcome } \\
\text { assessments) } \\
\text { FODMAP-restricted diet improved } \\
\text { overall IBS symptoms in all studies }\end{array}$ & - \\
\hline $\begin{array}{l}\text { Böhn et al, 2014(32); } \\
\text { Sweden }\end{array}$ & $\mathrm{RCT}$ & Rome III & $\begin{array}{l}\text { Sample size: } \\
\text { Intervention }(n=32) \text { vs. } \\
\text { control }(n=33) \\
\text { Intervention: low } \\
\text { FODMAP diet }(L F D) \text { vs. } \\
\text { traditional IBS dietary } \\
\text { advice } \\
\text { IBS SSS used } \\
\text { Study duration: } 4 \text { wk }\end{array}$ & $\begin{array}{l}\text { Dietary advice is efficient in reducing } \\
\text { the gastrointestinal symptoms of IBS. } \\
\text { LFD vs. traditional dietary advice: } \\
\text { - No difference in efficiency in } \\
\text { reduction of gastrointestinal } \\
\text { symptoms of IBS } \\
\text { - Response rate: } 18 \text { patients ( } 56 \%) \text { vs. } \\
17(52 \%)(p=0.70 \text { ) } \\
\text { - Equal response seen between } \\
\text { moderate }(p=0.62 \text { ) and } \\
\text { severe ( } p=0.90) \text { IBS patients } \\
\text { - Reduction in IBS SSS was similar } \\
\text { between the two groups ( } p=0.64) \\
\text { and among the individual items of } \\
\text { the IBS SSS score ( } p=0.69) \\
\text { - There was a trend toward a larger } \\
\text { reduction in abdominal distension in } \\
\text { the traditional diet group ( } p=0.08 \text { ) }\end{array}$ & 5 \\
\hline $\begin{array}{l}\text { Pedersen et al, 2014(33); } \\
\text { Denmark }\end{array}$ & Unblinded RCT & Rome III & $\begin{array}{l}\text { Sample size: } \\
\text { Intervention }(n=44) \text { vs. } \\
\text { control }(n=45) \\
\text { Intervention: LFD vs. } \\
\text { normal diet } \\
\text { IBS SSS used } \\
\text { Study duration: } 6 \text { wk }\end{array}$ & $\begin{array}{l}\text { Significant reduction in IBS SSS at } \\
\text { wk } 6 \text { in LFD compared to control } \\
\text { group ( } 114 \text { vs. } 68 ; p=0.02 \text { ) }\end{array}$ & 3 \\
\hline $\begin{array}{l}\text { Pedersen et al, 2014 }{ }^{(23)} \text {; } \\
\text { Denmark }\end{array}$ & Unblinded RCT & Rome III & $\begin{array}{l}\text { Sample size: } \\
\text { LFD ( } \mathrm{n}=42 \text { ); } \\
\text { Lactobacillus rhamnosus } \\
\text { GG (LGG) ( } \mathrm{n}=41 \text { ); } \\
\text { normal Danish diet (ND) } \\
\text { ( } \mathrm{n}=40 \text { ) } 5 \text { IBS-C, } 19 \\
\text { IBS-D, } 14 \text { IBS-M } \\
\text { Intervention: LFD, LGG } \\
\text { or ND } \\
3 \text { phases: } \\
\text { - 6-wk web-based } \\
\text { self-management } \\
\text { programme } \\
\text { - Dietician consult } \\
\text {-6-wk intervention diet } \\
\text { IBS SSS used } \\
\text { IBS QOL evaluated } \\
\text { Study duration: } 12 \text { wk }\end{array}$ & $\begin{array}{l}\text { Significant reduction in mean } \pm \text { SD of } \\
\text { IBS SSS from baseline to wk } 6 \text { between } \\
\text { LFD vs. LGG vs. ND: } 133 \pm 122 \text { vs. } 68 \pm \\
107 \text { vs. } 34 \pm 95 ; p<0.01 \\
\text { Adjusted changes of IBS SSS } \\
\text { for baseline covariates showed } \\
\text { statistically significant reduction } \\
\text { of IBS SSS in LFD compared to } \\
\text { ND group (IBS SSS score } 75 \text {; } 95 \% \\
\text { CI } 24-126, p<0.01 \text { ), but not in LGG } \\
\text { compared to ND group (IBS SSS score } \\
32 ; 95 \% \text { Cl } 18-80, p=0.20 \text { ) } \\
\text { IBS QOL was not altered significantly } \\
\text { in any of the } 3 \text { groups: mean } \pm \text { SD in } \\
\text { LFD ( } 8 \pm 18 \text { ) vs. LGG }(7 \pm 17) \text {, LFD ( } 8 \\
\pm 18) \text { vs. ND ( } 0.1 \pm 15) ; p=0.13 \\
\text { Improvement in symptom score was } \\
\text { more significant for IBS-D subtype } \\
\text { (320 } \pm 110 \text { to } 153 \pm 136, p<0.01 \text { ) }\end{array}$ & (1) \\
\hline $\begin{array}{l}\text { Halmos et al, 2014(27); } \\
\text { Australia }\end{array}$ & $\begin{array}{l}\text { Randomised } \\
\text { crossover trial }\end{array}$ & Rome III & $\begin{array}{l}\text { Sample size: } \\
\text { Intervention }(n=30) \text { vs. } \\
\text { control }(n=8) \\
13 \text { IBS-C, } 10 \text { IBS-D, } 5 \\
\text { IBS-M, } 2 \text { IBS-U } \\
\text { Intervention: LFD vs. } \\
\text { Australian diet } \\
\text { Goal: < } 0.5 \text { g FODMAP } \\
\text { per meal } \\
\text { Gastrointestinal } \\
\text { symptoms on VAS } \\
\text { Study duration: } 3 \text { wk }\end{array}$ & $\begin{array}{l}\text { Improvement in bloating on } \\
\text { visual analogue scale (VAS): LFD } \\
24.2(17.1-31.2) \text { vs. control } \\
45.1(35.1-55.0) \\
\text { Improvement in overall symptoms by } \\
70 \%(21 / 30) \\
\text { Daily gastrointestinal symptoms } \\
\text { on VAS: LFD } 22.8(16.7-28.8) \text { vs. } \\
\text { Australian diet } 44.9(36.6-53.1)\end{array}$ & 4 \\
\hline
\end{tabular}




\begin{tabular}{|c|c|c|c|c|c|}
\hline Study, year; country & Design & $\begin{array}{c}\text { IBS } \\
\text { classification }\end{array}$ & Characteristics & Results & $\begin{array}{l}\text { Quality of } \\
\text { RCT (Jadad } \\
\text { score) }\end{array}$ \\
\hline $\begin{array}{l}\text { Harvie et al, 2014 } \\
\text { New Zealand }\end{array}$ & RCT & Rome III & $\begin{array}{l}\text { Sample size: } \\
\text { intervention }(n=23) \\
\text { vs. control }(n=27) \\
\text { Intervention: LFD under } \\
\text { dietician guidance vs. } \\
\text { control } \\
\text { IBS SSS used } \\
\text { IBS QOL evaluated } \\
\text { Study duration: } 12 \text { wk }\end{array}$ & $\begin{array}{l}\text { Significant reduction in IBS SSS with } \\
\text { LFD }(275.6 \pm 63.6 \text { to } 128.8 \pm 82.5) \\
\text { vs. control group }(246.8 \pm 71.1 \text { to } \\
203.6 \pm 70.1) \text { ( } p<0.0002) \\
\text { Significant improvement in } \\
\text { QOL }(68.5 \pm 18.0 \text { to } 83 \pm 13.4) \\
\text { vs. control group }(72.9 \pm 12.8 \text { to } \\
73.3 \pm 14.4) \text { ( } p<0.0001) \\
\text { No improvement in severity of bloating }\end{array}$ & 5 \\
\hline $\begin{array}{l}\text { Staudacher et al, 2012 } \\
\text { United Kingdom }\end{array}$ & RCT & NICE & $\begin{array}{l}\text { Sample size: } \\
\text { intervention }(n=19) \text { vs. } \\
\text { control }(n=22) \\
\text { Intervention: LFD diet } \\
\text { vs. habitual diet } \\
\text { Composite endpoint } \\
\text { used } \\
\text { Study duration: } 4 \text { wk }\end{array}$ & $\begin{array}{l}\text { LFD resulted in a lower mean } \\
\text { daily severity score for bloating, } \\
0.9(0.6-1.1) \text { compared to } \\
\text { control } 1.4(1.2-1.6) \\
68 \% \text { of the intervention group } \\
\text { reported adequate control of } \\
\text { symptoms compared with } 23 \% \text { of the } \\
\text { control group }(p=0.005)\end{array}$ & 5 \\
\hline $\begin{array}{l}\text { Shepherd et al, } 2008^{(28)} \text {; } \\
\text { Australia }\end{array}$ & $\begin{array}{l}\text { Double-blind, } \\
\text { randomised, } \\
\text { quadruple-arm, } \\
\text { placebo-controlled } \\
\text { re-challenge } \\
\text { trial }\end{array}$ & - & $\begin{array}{l}\text { Sample size: } \mathrm{n}=25 \\
\text { Intervention: Graded } \\
\text { dose of fructose/fructan, } \\
\text { alone or in combination, } \\
\text { or glucose taken as } \\
\text { drinks with meals } \\
\text { Gastrointestinal } \\
\text { symptoms on VAS } \\
\text { Study duration: } 22 \mathrm{wk}\end{array}$ & $\begin{array}{l}\text { Improvement of bloating and } \\
\text { symptom relapse (gas, bloating } \\
\text { and pain) seen more in IBS } \\
\text { patients on fructose-fructan } \\
\text { mix }(79 \%) \text { vs. fructose }(70 \%) \text { and } \\
\text { fructan }(77 \%) \text { compared to } 14 \% \text { on } \\
\text { glucose ( } p<0.001) \\
\text { Reduction in severity of overall and } \\
\text { individual symptoms with baseline } \\
\text { diet } \\
\text { Intensity of overall symptoms } \\
\text { increased as the dose of fructose, } \\
\text { fructan, and fructose-fructan mix } \\
\text { increased ( } p<0.01 \text { ) } \\
\text { Fructose-fructan mix caused greater } \\
\text { symptom severity. No difference } \\
\text { in symptoms between fructan or } \\
\text { fructose alone }\end{array}$ & 5 \\
\hline $\begin{array}{l}\text { Pedersen et al, 2014 }{ }^{(34)} \\
\text { Denmark }\end{array}$ & $\begin{array}{l}\text { Single-blind } \\
\text { crossover trial }\end{array}$ & Rome III & $\begin{array}{l}\text { Sample size: } \mathrm{n}=19 \\
\text { Intervention: LFD advice } \\
\text { by FODMAP-certified } \\
\text { dietician } \\
\text { IBS SSS used } \\
\text { Study duration: } 6 \mathrm{wk}\end{array}$ & $\begin{array}{l}\text { Significant symptom reduction IBS } \\
\text { SSS was observed from wk } 6-12 \\
\text { in all patients, with remission in } \\
57.9 \%(11 / 19) \text { of patients }\end{array}$ & 4 \\
\hline $\begin{array}{l}\text { Ong et al, 2010(29); } \\
\text { Australia }\end{array}$ & $\begin{array}{l}\text { Single-blind, } \\
\text { crossover } \\
\text { intervention trial }\end{array}$ & - & $\begin{array}{l}\text { Sample size: } 15 / 15 \\
\text { Intervention: low } \\
\text { ( } 9 \mathrm{~g} / \text { day) vs. high } \\
\text { ( } 50 \mathrm{~g} / \text { day) FODMAP diet } \\
\text { Daily gastrointestinal } \\
\text { symptom score (3-point } \\
\text { Likert scale) } \\
\text { Study duration: } 2 \text { days } \\
\text { per diet }\end{array}$ & $\begin{array}{l}\text { Composite endpoint for bloating was } \\
\text { significantly higher in IBS patients } \\
\text { on high FODMAP diet (median } 6 ; \\
\text { range } 2-9 \text { ) than LFD (median 2; } 0-7 ; \\
p=0.002 \text { ) } \\
\text { Improvement in bloating symptoms } \\
\text { was significantly higher in IBS } \\
\text { patients switching from high FODMAP } \\
\text { diet (median } 3 ; \text { range } 0-3 \text { ) than } \\
\text { LFD (median } 1 ; 0-3 ; p=0.002 \text { ) }\end{array}$ & 3 \\
\hline Ostgaard et al, $2012^{(46)}$ & $\begin{array}{l}\text { Non-randomised } \\
\text { comparative trial }\end{array}$ & - & $\begin{array}{l}\text { Sample size: } 43 / 36 / 35 \\
\text { Intervention: IBS with } \\
\text { LFD advice vs. IBS vs. } \\
\text { control } \\
\text { Duration of study: not } \\
\text { mentioned }\end{array}$ & $\begin{array}{l}\text { No statistical differences in the intake } \\
\text { of calories, carbohydrates, proteins } \\
\text { and fat between the control group and } \\
\text { IBS patients, with or without guidance } \\
\text { on diet management } \\
\text { Guidance on the management of diet } \\
\text { improved their choice of a healthier } \\
\text { diet, improved IBS symptoms and QOL }\end{array}$ & 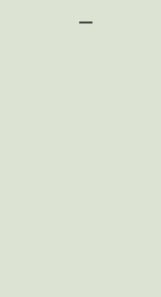 \\
\hline
\end{tabular}




\begin{tabular}{|c|c|c|c|c|c|}
\hline Study, year; country & Design & $\begin{array}{c}\text { IBS } \\
\text { classification }\end{array}$ & Characteristics & Results & $\begin{array}{l}\text { Quality of } \\
\text { RCT (Jadad } \\
\text { score) }\end{array}$ \\
\hline $\begin{array}{l}\text { Staudacher et al, 2011 } \\
\text { United Kingdom }\end{array}$ & $\begin{array}{l}\text { Non-randomised } \\
\text { comparative trial }\end{array}$ & NICE & $\begin{array}{l}\text { Sample size: } 43 / 39 \\
\text { Intervention: Written } \\
\text { information on standard } \\
\text { vs. LFD advice based } \\
\text { on NICE guideline } \\
2008 \text { (standard) } \\
\text { Validated IBS } \\
\text { global improvement } \\
\text { scale (7-point Likert } \\
\text { scale) } \\
\text { Study duration: } 8-24 \text { wk }\end{array}$ & $\begin{array}{l}76 \% \text { of patients responded well to } \\
\text { LFD compared with a cohort treated } \\
\text { by conventional dietary restriction, in } \\
\text { whom } 50 \% \text { responded } \\
\text { LFD vs. standard diet: } \\
\text { - Improved composite endpoint: } 86 \% \\
\text { vs. } 49 \% \text { ( } p<0.001) \\
\text { - Improved bloating }(32 / 39) 82 \% \\
\text { vs. }(17 / 35) 49 \% \text { ( } p=0.002) \\
\text { - Improved flatulence: } 87 \% \text { vs. } \\
50 \%(p=0.001)\end{array}$ & - \\
\hline Whigham et al, $2015^{(45)}$ & Prospective study & - & $\begin{array}{l}\text { Sample size: } \mathrm{n}=364 \\
\text { Intervention: Dietitian-led } \\
\text { group education vs. } \\
\text { traditional one-to-one } \\
\text { education } \\
\text { Global symptom } \\
\text { questionnaire }\end{array}$ & $\begin{array}{l}\text { Significant decrease in symptom } \\
\text { severity from baseline to } \\
\text { follow-up ( } p<0.001 \text { for both groups) } \\
\text { More patients were satisfied with their } \\
\text { symptoms following: } \\
\text { - Dietary advice: baseline } 48 / 263(18 \%) \\
\text { vs. follow-up } 142 / 263(54 \%), p<0.001 \\
\text { - One-to-one education: baseline } \\
5 / 101(5 \%) \text { vs. follow-up } \\
61 / 101(60 \%), p<0.001 \\
\text { No difference between group } \\
\text { and one-to-one education at } \\
\text { follow-up ( } p=0.271 \text { ) }\end{array}$ & (1) \\
\hline $\begin{array}{l}\text { Huamán et al, 2015(22); } \\
\text { Spain }\end{array}$ & $\begin{array}{l}\text { Prospective } \\
\text { observational } \\
\text { study }\end{array}$ & Rome III & $\begin{array}{l}\text { Sample size: } \mathrm{n}=30 \\
\text { Intervention: LFD by } \\
\text { expert dietician } \\
\text { Overall and specific } \\
\text { symptom questionnaire } \\
\text { (10-point Likert scale) } \\
\text { Study duration: } 8 \text { wk }\end{array}$ & $\begin{array}{l}\text { LFD controlled overall symptoms and } \\
\text { specific symptoms such as bloating } \\
\text { and flatulence in more than } 70 \% \text { of } \\
\text { patients }(p<0.05)\end{array}$ & - \\
\hline $\begin{array}{l}\text { de Roest et al, } 2013^{(31)} \text {; } \\
\text { New Zealand }\end{array}$ & $\begin{array}{l}\text { Prospective } \\
\text { observational } \\
\text { study }\end{array}$ & - & $\begin{array}{l}\text { Sample size: } \mathrm{n}=90 \\
\text { Intervention: Dietician } \\
\text { consultation on LFD } \\
\text { Gastrointestinal symptom } \\
\text { score on VAS (7-point } \\
\text { Likert scale) } \\
\text { Duration of study: } \\
68 \text { wk (mean) }\end{array}$ & $\begin{array}{l}\text { Most symptoms demonstrated a } \\
\text { significant improvement }(\mathrm{p}<0.001) \\
\text { Patients with fructose malabsorption } \\
\text { significantly more likely to report } \\
\text { symptom improvement: } \\
\text { - Bloating (OR } 8.71,95 \% \mathrm{Cl} 2.76-27.5) \text {, } \\
\text { - Flatulence (OR } 7.64,95 \% \mathrm{Cl} \\
2.53-23.0) \\
\text { - } p<0.029 \text { for all } \\
\text { - Most }(72.1 \% \text { ) were satisfied with } \\
\text { their symptoms }\end{array}$ & - \\
\hline $\begin{array}{l}\text { Mazzawi et al, 2013(38); } \\
\text { Norway }\end{array}$ & Case study & Rome III & $\begin{array}{l}\text { Sample size: } \mathrm{n}=17 \\
8 \text { IBS-C subtype, } 6 \text { IBS-D } \\
\text { subtype, } 3 \text { IBS-M subtype } \\
\text { Intervention: } \mathrm{n}=3 \\
\text { sessions of } 45-\mathrm{min} \\
\text { nurse-administered } \\
\text { dietary guidance } \\
\text { - Birmingham IBS Score } \\
\text { questionnaire } \\
\text { - MoBa Food Frequency } \\
\text { Questionnaire } \\
\text { - IBS QOL } \\
\text { - Short-Form Nepean } \\
\text { and Dyspepsia } \\
\text { Index (SF-NDI) HRQoL } \\
\text { questionnaire } \\
\text { Study duration: 3-9 mth } \\
\text { (median } 4 \text { mth) }\end{array}$ & $\begin{array}{l}\text { Reduced the symptoms and improved } \\
Q O L \text { of patients with IBS: } \\
\text { - Improvement in IBS symptom score } \\
\text { with intervention }(41.47 \pm 1.62 \text { to } \\
35.71 \pm 1.12, p=0.001) \\
\text { - Improvement in } Q O L \text { with } \\
\text { intervention ( } 125.4 \pm 4.2 \text { to } \\
136.8 \pm 3.8, p=0.003 \text { ) } \\
\text { - Improvement in health-related } \\
Q O L \text { (HRQ L ): total SF-NDI scores } \\
\text { from } 29.1 \pm 2.2 \text { and } 20.2 \pm 1.5 \text {, } \\
p=0.002 \\
\text { Individual dietary guidance is } \\
\text { a cost-effective option for the } \\
\text { management of IBS }\end{array}$ & - \\
\hline
\end{tabular}




\begin{tabular}{|c|c|c|c|c|c|}
\hline Study, year; country & Design & $\begin{array}{c}\text { IBS } \\
\text { classification }\end{array}$ & Characteristics & Results & $\begin{array}{c}\text { Quality of } \\
\text { RCT (Jadad } \\
\text { score) }\end{array}$ \\
\hline $\begin{array}{l}\text { Hookway et al, } 2015^{(44)} \text {; } \\
\text { United Kingdom }\end{array}$ & $\begin{array}{l}\text { Evidence-based } \\
\text { CPG } 2015\end{array}$ & - & - & - & - \\
\hline $\begin{array}{l}\text { Brandt et al, 2009(10); } \\
\text { United States }\end{array}$ & $\begin{array}{l}\text { Evidence-based } \\
\text { position } \\
\text { statement }\end{array}$ & - & - & - & - \\
\hline McKenzie et al, $2012^{(48)}$ & $\begin{array}{l}\text { Evidence-based } \\
\text { guidelines } 2012\end{array}$ & - & - & - & - \\
\hline
\end{tabular}

$\mathrm{Cl}$ : confidence interval; CPG: clinical practice guideline; FODMAP: fermentable oligosaccharides, disaccharides, monosaccharides and polyols; IBS: irritable bowel syndrome; MoBa: Norwegian Mother and Child Cohort Study; NICE: National Institute for Health and Care Excellence; OR: odds ratio; RCT: randomised controlled trial; SD: standard deviation; SSS: symptom severity score

Table II. Recommendations based on Strength of Recommendation Taxonomy (SORT).(26)

\begin{tabular}{llc}
\hline Recommendation & Grade & $\begin{array}{c}\text { Reference } \\
\text { No. }\end{array}$ \\
\hline $\begin{array}{l}\text { General lifestyle and dietary advice } \\
\text { should be given to irritable bowel } \\
\text { syndrome (IBS) patients }\end{array}$ & C & $10,43,48$ \\
$\begin{array}{l}\text { IBS patients with bloating symptoms } \\
\text { should receive guidance on low }\end{array}$ & B & 46 \\
$\begin{array}{l}\text { FODMAP diet (LFD) management to } \\
\text { improve quality of life }\end{array}$ & A & $27,28,29$, \\
$\begin{array}{l}\text { IBS patients with disturbing } \\
\text { bloating symptoms should be } \\
\text { offered an eight-week trial of a }\end{array}$ & & $34,35,37$ \\
$\begin{array}{l}\text { FODMAP-restricted diet } \\
\text { A FODMAP-restricted diet should } \\
\text { form an integral part of the holistic } \\
\text { management of diarrhoeal-predominant } \\
\text { IBS patients with bloating }\end{array}$ & A & \\
$\begin{array}{l}\text { A FODMAP-restricted diet may be } \\
\text { considered in the treatment of IBS } \\
\text { patients with bloating and concomitant } \\
\text { fructose malabsorption }\end{array}$ & & 33 \\
$\begin{array}{l}\text { Constipation should be adequately and } \\
\text { aggressively managed before offering } \\
\text { an LFD to constipation-predominant } \\
\text { IBS patients }\end{array}$ & C & \\
\hline
\end{tabular}

SORT evidence rating system: A: consistent, good-quality, patient-oriented evidence; B: inconsistent or limited-quality, patient-oriented evidence; C: consensus, disease-oriented evidence, usual practice, expert opinion or case series. FODMAP: fermentable oligosaccharides, disaccharides, monosaccharides and polyols

\section{REFERENCES}

1. Gwee KA, Bak YT, Ghoshal UC, et al; Asian Neurogastroenterology and Motility Association. Asian consensus on irritable bowel syndrome. J Gastroenterol Hepatol 2010; 25:1189-205.

2. Markowitz MA, Jhingran P, Asgharian A, et al. IBS prevalence: results from a community based patient registry based on the Rome II criteria. Am J Gastroenterol 2000; 95:2634.

3. Fedewa A, Rao SS. Dietary fructose intolerance, fructan intolerance and FODMAPs. Curr Gastroenterol Rep 2014; 16:370.

4. Mertz HR. Irritable bowel syndrome. N Engl J Med 2003; 349:2136-46.

5. Thompson WG, Longstreth GF, Drossman DA, et al. Functional bowel disorders and functional abdominal pain. Gut 1999; 45 Suppl 2:II43-7.

6. Longstreth GF, Thompson WG, Chey WD, et al. Functional bowel disorders. Gastroenterology 2006; 130:1480-91.

7. Talley NJ, Boyce P, Jones M. Identification of distinct upper and lower gastrointestinal symptom groupings in an urban population. Gut 1998; 42:690-5.

8. Tuteja AK, Talley NJ, Joos SK, Tolman KG, Hickam DH. Abdominal bloating in employed adults: prevalence, risk factors, and association with other bowel disorders. Am J Gastroenterol 2008; 103:1241-8.

9. Sandler RS, Stewart WF, Liberman JN, Ricci JA, Zorich NL. Abdominal pain, bloating, and diarrhea in the United States: prevalence and impact. Dig Dis Sci 2000; 45:1166-71.

10. American College of Gastroenterology Task Force on Irritable Bowel Syndrome; Brandt LJ, Chey WD, et al. An evidence-based position statement on the management of irritable bowel syndrome. Am J Gastroenterol 2009; 104 Suppl 1: S1-35.

11. Jones J, Boorman J, Cann P, et al. British Society of Gastroenterology guidelines for the management of irritable bowel syndrome. Gut 2000; 47 Suppl 2:ii1-19.

12. Böhn L, Störsrud S, Törnblom H, Bengtsson U, Simrén M. Self-reported food-related gastrointestinal symptoms in IBS are common and associated with more severe symptoms and reduced quality of life. Am J Gastroenterol 2013; 108:634-41.

13. Hayes P, Corish C, O'Mahony E, Quigley EM. A dietary survey of patients with irritable bowel syndrome. J Hum Nutr Diet 2014; 27 Suppl 2:36-47.

14. Heizer WD, Southern S, McGovern S. The role of diet in symptoms of irritable bowel syndrome in adults: a narrative review. J Am Diet Assoc 2009; 109:1204-14.

15. Locke GR 3rd, Zinsmeister AR, Talley NJ, Fett SL, Melton LJ. Risk factors for irritable bowel syndrome: role of analgesics and food sensitivities. Am J Gastroenterol 2000; 95:157-65.

16. Monsbakken KW, Vandvik PO, Farup PG. Perceived food intolerance in subjects with irritable bowel syndrome-- etiology, prevalence and consequences. Eur J Clin Nutr 2006; 60:667-72.

17. Halpert A, Dalton CB, Palsson O, et al. What patients know about irritable bowel syndrome (IBS) and what they would like to know. National Survey on Patient Educational Needs in IBS and development and validation of the Patient Educational Needs Questionnaire (PEQ). Am J Gastroenterol 2007; 102:1972-82.

18. Parker K, Salas M, Nwosu VC. High fructose corn syrup: production, uses and public health concerns. Biotechnol Mol Biol Rev 2010; 5:71-8.

19. Fernández-Bañares $F$, Rosinach $M$, Esteve $M$, et al. Sugar malabsorption in functional abdominal bloating: a pilot study on the long-term effect of dietary treatment. Clin Nutr 2006; 25:824-31.

20. Goldstein R, Braverman D, Stankiewicz H. Carbohydrate malabsorption and the effect of dietary restriction on symptoms of irritable bowel syndrome and functional bowel complaints. Isr Med Assoc J 2000; 2:583-7.

21. Sharara Al, Aoun E, Abdul-Baki H, et al. A randomized double-blind placebo-controlled trial of rifaximin in patients with abdominal bloating and flatulence. Am J Gastroenterol 2006; 101:326-33.

22. Huamán JW, Felip A, Guedea E, et al. [The diet low in fermentable carbohydrates short chain and polyols improves symptoms in patients with functional gastrointestinal disorders in Spain]. Gastroenterol Hepatol 2015; 38:113-22. Spanish.

23. Pedersen N, Ankersen DV, Felding M, et al. M01210 Low FODMAP diet reduces irritable bowel symptoms and improves quality of life in patients with inflammatory bowel disease in a randomized controlled trial. Gastroenterol 2014; 146 (Suppl 1):S-587.

24. Harvie R. A reduction in FODMAP intake correlates strongly with a reduction in IBS symptoms-The FIBS study (thesis). Dunedin, New Zealand: University of Otago, 2014

25. Jadad AR, Moore RA, Carroll D, et al. Assessing the quality of reports of randomized clinical trials: is blinding necessary? Controlled Clin Trials 1996; 17:1-12.

26. Ebell MH, Siwek J, Weiss BD, Woolf SH, Susman J, Ewigman B, et al. 
Strength of Recommendation Taxonomy (SORT): a patient-centered approach to grading evidence in the medical literature. Am Fam Physician 2004;69:549-57.

27. Halmos EP, Power VA, Shepherd SJ, Gibson PR, Muir JG. A diet low in FODMAPs reduces symptoms of irritable bowel syndrome. Gastroenterology 2014; 146:67-75.e5.

28. Shepherd SJ, Parker FC, Muir JG, Gibson PR. Dietary triggers of abdominal symptoms in patients with irritable bowel syndrome: randomized placebocontrolled evidence. Clin Gastroenterol Hepatol 2008; 6:765-71.

29. Ong DK, Mitchell SB, Barrett JS, et al. Manipulation of dietary short chain carbohydrates alters the pattern of gas production and genesis of symptoms in irritable bowel syndrome. J Gastroenterol Hepatol 2010; 25:1366-73

30. Staudacher HM, Whelan K, Irving PM, Lomer MC. Comparison of symptom response following advice for a diet low in fermentable carbohydrates (FODMAPs) versus standard dietary advice in patients with irritable bowe syndrome. J Hum Nutr Diet 2011; 24:487-95.

31. de Roest RH, Dobbs BR, Chapman BA, et al. The low FODMAP die improves gastrointestinal symptoms in patients with irritable bowel syndrome: a prospective study. Int J Clin Pract 2013; 67:895-903.

32. Böhn L, Störsrud S, Liljebo T, et al. A multi-center, randomized, controlled, single-blind, comparative trial: low-FODMAP diet versus traditional dietary advice in IBS. United Eur Gastroenterol J 2014; 2(1 Suppl):A1-A131.

33. Pedersen N, Andersen NN, Végh Z, et al. Ehealth: low FODMAP die vs Lactobacillus rhamnosus GG in irritable bowel syndrome. World Gastroenterol 2014; 20:16215-26.

34. Pedersen N, Vegh Z, Burisch J, et al. Ehealth monitoring in irritable bowel syndrome patients treated with low fermentable oligo-, di-, monosaccharides and polyols diet. World J Gastroenterol 2014; 20:6680-4.

35. Francis CY, Morris J, Whorwell PJ. The irritable bowel severity scoring system: a simple method of monitoring irritable bowel syndrome and its progress. Aliment Pharmacol Ther 1997; 11:395-402.

36. Rao SS, Yu S, Fedewa A. Systematic review: dietary fibre and FODMAPrestricted diet in the management of constipation and irritable bowel syndrome. Aliment Pharmacol Ther 2015; 41:1256-70.

37. Marsh A, Eslick EM, Eslick GD. Does a diet low in FODMAPs reduce symptoms associated with functional gastrointestinal disorders? A comprehensive systematic review and meta-analysis. Eur J Nutr 2015 May 17. [Epub ahead of print]

38. Mazzawi T, Hausken T, Gundersen D, El-Salhy M. Effects of dietary guidance on the symptoms, quality of life and habitual dietary intake of patients with irritable bowel syndrome. Mol Med Rep 2013; 8:845-52.
39. Barrett JS, Gibson PR. Fermentable oligosaccharides, disaccharides, monosaccharides and polyols (FODMAPs) and nonallergic food intolerance: FODMAPs or food chemicals? Therap Adv Gastroenterol 2012; 5:261

40. Julie Pildal, An-Wen Chan, Asbjørn Hróbjartsson, Elisabeth Forfang, Douglas G Altman, Peter C Gøtzsche. Comparison of descriptions of allocation concealment in trial protocols and the published reports: cohort study. BMJ 2005; 330 doi: http://dx.doi.org/10.1136/bmj.38414.422650.8F (Published 05 May 2005).

41. Ng SC. Inflammatory bowel disease in Asia. Gastroenterol Hepatol (N Y) 2013; 9:28-30.

42. Ooi CJ, Hilmi I, Makharia GK, et al; Asia Pacific Association of Gastroenterology (APAGE) Working Group on Inflammatory Bowel Disease. The Asia Pacific Consensus Statements on Crohn's Disease Part 1: definition, diagnosis and epidemiology. J Gastroenterol Hepatol 2015 Mar 25. [Epub ahead of print]

43. National Collaborating Centre for Nursing and Supportive Care (UK). Irritable Bowel Syndrome in Adults: Diagnosis and Management of Irritable Bowel Syndrome in Primary Care [Internet]. London: Royal College of Nursing (UK), 2008.

44. Hookway C, Buckner S, Crosland P, Longson D. Irritable bowel syndrome in adults in primary care: summary of updated NICE guidance. BMJ 2015; 350:h701.

45. Whigham L, Joyce $T$, Harper $G$, et al. Clinical effectiveness and economic costs of group versus one-to-one education for short-chain fermentable carbohydrate restriction (low FODMAP diet) in the management of irritable bowel syndrome. J Hum Nutr Diet 2015 Apr 14. [Epub ahead of print]

46. Ostgaard H, Hausken T, Gundersen D, El-Salhy M. Diet and effects of diet management on quality of life and symptoms in patients with irritable bowel syndrome. Mol Med Rep 2012; 5:1382-90.

47. Foley A, Burgell R, Barrett JS, Gibson PR. Management strategies for abdominal bloating and distension. Gastroenterol Hepatol 2014; 10:561-71.

48. McKenzie YA, Alder A, Anderson W, et al; Gastroenterology Specialist Group of the British Dietetic Association. British Dietetic Association evidence-based guidelines for the dietary management of irritable bowel syndrome in adults. J Hum Nutr Diet 2012; 25:260-74.

49. Staudacher HM, Lomer MC, Anderson JL, et al. Fermentable carbohydrate restriction reduces luminal bifidobacteria and gastrointestinal symptoms in patients with irritable bowel syndrome. J Nutr 2012; 142:1510-8.

\section{APPENDIX}

\section{IBS Symptom Severity Score Questionnaire}

(1)

a. Do you currently suffer from abdominal pain?

b. If yes, how severe is your abdominal pain?

$$
0 \%
$$
$100 \%$

Enter the number of days that you experience symptoms.

$$
\square \times 10
$$

$(2)$

a. Do you currently suffer from abdominal distention and bloating?

b. If yes, how severe is your abdominal pain?

$$
\text { 0\%------------------100\% }
$$

(3) How satisfied are you with your bowel habits?

$$
\text { 0\%-------------------100\% }
$$

(4) Indicate with an ' $X$ ' on the line below how much IBS is affecting or interfering with your life.

$$
\text { 0\%---------------------100\% }
$$

Severe : $301-500$

Moderate: $176-300$

Mild : : 75-175 